Brit. J. industr. Med., 1961, 18, 130.

\title{
HISTAMINE LIBERATION BY COTTON DUST EXTRACTS : EVIDENCE AGAINST ITS CAUSATION BY BACTERIAL ENDOTOXINS
}

\author{
BY \\ H. ANTWEILER \\ From the Silicosis Research Department of the Rheinpreussen AG, Homberg- Niederrhein, Germany
}

(RECEIVED FOR PUBLICATION OCTOBER 5, 1960)

\begin{abstract}
The recently stated hypothesis that histamine liberation by cotton dust extracts is caused by endotoxins from gram-negative bacteria contained in cotton was studied experimentally in various animals. It was shown clearly that such amounts of endotoxin as were found in cotton dust did not give rise to histamine liberation which was provoked by extracts from cotton card-room dusts. Further arguments are given which testify against the endotoxin hypothesis.
\end{abstract}

We have recently shown in various animal experiments that aqueous extracts of several cotton materials (raw cotton, card-room dust, and shreds from the carding machines) and extracts of certain parts of the cotton plant (leaves, stem, and seed capsule fragments) contain a histamine-liberating factor. The biological activity of this factor is much greater than that of the actual histamine content of the dusts or plant tissues used (Antweiler, 1959a; 1960a, b, c). Thus, for the first time, we can furnish evidence in favour of the hypothesis put forward by Haworth and Macdonald (1937) and recently by Bouhuys (1959) and Bouhuys, Lindell, and Lundin (1960).

From the results of these experiments we infer that there may be a relationship between the histamine-liberating factor in cotton dust and the dyspnoeic Monday feeling of card-room workers, recently described by Schilling $(1956,1960)$ and Roach and Schilling (1960). The chemical nature of the histamine-liberating factor which is heatresistant and passes protein-tight membrane filters is still unknown.

Pernis (1960) has recently confirmed our findings. Moreover, he has succeeded in producing anaphylatoxin by incubating rat plasma with cotton dust extracts and has observed a pyrogenic effect after intravenous injection of cotton extract in rabbits. By comparing the phenomena brought about in animals by parenteral application of cotton extracts with the similar action of endotoxins of gramnegative bacteria (E. coli, S. abort. equi, S. typhi, Aerobacter cloacae) described in the literature,
Pernis concluded that the histamine-liberating factor of cotton extracts might be due to the presence of the endotoxins of bacteria, found in the raw cotton used in cotton-spinning.

In cotton dust samples from America and India which liberate histamine, we had found aerobe spore bacteria such as $B$. subtilis, $B$. megaterium and $B$. cereum and also fungi like Asperg. niger and $A$. flavus. Using homogenates of cultures from these bacteria we could not observe any histamine liberation in our animal experiments. We thought therefore that the histamine release caused by cotton extracts was not produced by bacteria or bacterial substances.

Because of Pernis' hypothesis we undertook some experiments to find out whether well-known endotoxins induce rapid histamine liberation when they are employed in such quantities as might be contained in industrial cotton dusts or cotton plant fragments.

\section{Experimental Methods}

We chose the endotoxins from $S$. abort. equi (Pyrexal) and from E. coli 0111 (Dr. A. Wander Forschungsinstitut). The experimental methods were the same as we had used earlier (Antweiler, 1960a) in proving histamine liberation by cotton extracts. We injected the endotoxins intraperitoneally into rats and looked for microscopical variations of the mast cells of the mesentery and determined the amount of histamine present in the abdominal fluid. Heparinized rabbit blood was incubated at $37^{\circ} \mathrm{C}$. with the endotoxins, and afterwards we tested the histamine content of the plasma. The endotoxin 
action on blood pressure and respiration of anaesthetized cats was examined.

The endotoxins were dissolved in physiological saline to the same dilutions as used in the cotton extract experiments. All other details of the experimental procedures (animals, time relations, temperature, fixation and staining, and recording) were similar to our former trials. The histamine content was assayed on isolated and atropinized $\left(10^{-7}\right.$ atropine sulphate) guinea-pig ileum, suspended in aerated tyrode-solution at $30^{\circ} \mathrm{C}$., and compared by adding a standard solution of histaminedihydrochloride $\left(10^{-5}\right)$.

We also tried to verify the anaphylatoxic potency of cotton dust extracts in rat plasma and to compare this activity with the proportion of anaphylatoxin elicited by endotoxins. For this purpose we incubated 2 volumes of rat plasma with 1 volume of cotton card-room dust extract and endotoxin respectively in tyrode-solution during $30 \mathrm{~min}$. at $37^{\circ} \mathrm{C}$. Endotoxin from $S$. abort. equi was added in a dose of $0.5 \mu \mathrm{g}$. and the $E$. coliendotoxin in doses of $1 \mu \mathrm{g}$., $10 \mu \mathrm{g}$., and $100 \mu \mathrm{g}$. to every $3 \mathrm{ml}$. of rat plasma. In some experiments we also tested the anaphylatoxic activity of different samples of dry cotton, wool, and some mineral substances. The anaphylatoxin formation by dextran $(20 \mathrm{mg}$.) served as a comparable standard. In order to be certain that the anaphylatoxic activity of cotton dust extracts was not produced by the histamine known to be present in cotton dust, we tested the activity of equal doses of cotton extracts with and without rat plasma incubation.

\section{Results}

Examining the effect of the two endotoxins in concentrations of 0.1 to $10.0 \mu \mathrm{g}$. in $20 \mathrm{ml}$. tyrodesolution two hours after injection into the peritoneal cavity of rats, we were unable to detect any noticeable mast cell destruction or change of metachromatic staining of these cells. When withdrawn 20 minutes after administration, it was shown by testing it on guinea-pig ileum that there was no release of histamine in the peritoneal fluid.

After incubation of $5 \mathrm{ml}$. of rabbit blood with 0.1-1.0 $\mu \mathrm{g}$. of endotoxin from $S$. abort. equi or with $0.1-10.0 \mu \mathrm{g}$. of $E$. coli-endotoxin at $37^{\circ} \mathrm{C}$. for 10 minutes, no increase of plasma histamine was found as compared with the control samples incubated only with tyrode-solution.

When $0 \cdot 1,1 \cdot 0$ or $2 \cdot 0 \mu \mathrm{g}$. of endotoxin from S. abort. equi or 1.0 to $10.0 \mu \mathrm{g}$. of coli-endotoxin $/ \mathrm{kg}$. body weight were injected intravenously in chloralose-urethane anaesthetized cats, there was no delayed, profound and sustained fall in arterial blood pressure, as is always evoked by the histamine liberator $48 / 80$ or by extracts of cotton card-room dusts. Even when the examination was continued for 30 minutes, no definite changes in blood pressure were observed. The recording of respiratory volumes by the method of Konzett-Rössler also yielded no variation after injection of endotoxins.
In testing the activation of anaphylatoxin in rat plasma by incubation with endotoxins, it was noticed that $100 \mu \mathrm{g}$. of coli-endotoxin caused a weaker activation of anaphylatoxin than an extract from only $200 \mathrm{mg}$. cotton card-room dust. This amount of $100 \mu \mathrm{g}$. of endotoxin corresponds to nearly $50-100 \mathrm{mg}$. of dried bacteria, but there cannot be this quantity of bacteria in $200 \mathrm{mg}$. of cotton dust.

Boiling of acidified cotton extracts $(p \mathrm{H} 3)$ for 30 minutes did not influence the anaphylatoxic activity when tested after neutralization. Endotoxin solutions, on the contrary, lost their activity completely by this procedure.

The other materials examined for anaphylatoxic potency (dry clean cotton and wool and mineral dusts, i.e. quartz, rock crystal, quartz glass, Kieselguhr, titandioxide) yielded negative results. Dry raw cotton dust mixed with rat plasma produced the same activity as cotton dust extracts containing an equal quantity of cotton dust.

\section{Discussion}

It is well known that much larger doses of endotoxins than we used induce the shock syndrome with acute fall of blood pressure and disturbance of respiration when they are given by intravenous injection to cats (Gilbert, 1959) or dogs (Davis, Meeker, and McQuarrie, 1960). These effects are probably caused by rapid histamine liberation (Greisman, 1960). The doses of endotoxins used by these authors $(1.0-10.0 \mathrm{mg} . / \mathrm{kg}$. body weight) were considerably greater than the amounts which could be contained in our cotton dust extracts, the active extract doses of which corresponded to 200-400 mg. dust. These quantities of dust cannot possibly contain as much as $1 \mathrm{mg}$. endotoxin. The water content of bacteria is $80-90 \%$ and the dust would have to contain 50 to $100 \mathrm{mg}$. of dry bacterial substance, since the amount of endotoxin in dried bacteria is only $1-2 \%$.

There is still another argument which testifies against the endotoxin nature of the histamineliberating factor in cotton dust, namely, that boiling an acidified cotton extract does not lower its activity as an anaphylatoxin producer. Endotoxin solutions, however, do lose their activity by this procedure. Furthermore, it would not be compatible with the endotoxin hypothesis that the different parts of the cotton plant contain different amounts of the histamine-liberating factor, especially as those plant tissues which are most contaminated by handling, that is, cotton hairs, have no histamine-liberating activity. Also it does not seem reasonable to suppose that endotoxins of gram-negative bacteria are only allied with cotton dust and not with other dusts of similar physical and chemical character. 
Finally it must be pointed out that the symptoms after inhalation of cotton card-room dust in man (tightness of the chest, cough, and breathlessness) are not the same as the responses after application of endotoxins. For example, fever seldom occurs in cotton workers with severe Monday feeling (Müller, 1959), whereas endotoxins ("pyrogens") always cause fever whenever they cause substantial symptoms.

We think, now as before, that the histamineliberating factor in cotton dust is essentially bound to a pharmacologically active substance of the cotton plant itself. It is noteworthy that other naturally occurring substances such as cowhage from Mucuna pruriens (Broadbent, 1953), thalassine from sea anemone (Jaques and Schachter, 1954) and flax (Antweiler, 1959b) contain histamine liberators.

I am greatly indebted to Professor $O$. Westphal of the Dr. A. Wander Forschungsinstitut for supplying purified endotoxin from $E$. coli $\mathbf{0} \cdot 111$ and for his advice in the preparation of endotoxin solutions. I wish to thank Dr. E. Hirsch (of the bacteriological department of Rheinpreussen AG) very much for isolating, identifying, and culturing the micro-organisms in cotton dust. For technical assistance I am grateful to Mrs. Karentz and Mrs. Müller.

\section{REFERENCES}

Antweiler, H. (1959a). Naturwissenschaften, 46, 493.

- (1959b). Unpublished results.

(1960a). Arch. Gewerbepath. Gewerbehyg., 17, 574.

(1960b). Med d Lavoro $5 \mathrm{i}, 768$.

(1960b). Med. d. Lavoro, 51, 768.

Bouhuys, A. (1959). Ned. T. Geneesk, 103, 2356

Bouhuys, A. (1959). Ned. T. Geneesk, 103, 2356.

Broadindell, S. E., and Lundin, G. (1960). Brit. med. J., 1, 324

Broadbent, J. L. (1953). Brit. J. Pharmacol., 8, 263.

Davis, R. B., Meeker, W. R., and McQuarrie, D. G. (1960). Circulat. Res., 8, 234.

Gilbert, R.P. (1959). Proc. Soc. exp. Biol. (N. Y.), 100, 346.

Greisman, S. E. (1960). Ibid., 103, 628.

Haworth, E., and Macdonald, A. D. (1937). J. Hyg. (Lond.), 37, 234.

Jaques, R., and Schachter, M. (1954). Brit. J. Pharmacol., 9, 49.

Müller, L. (1959). Personal communication.

Pernis, B. (1960). Med. d. Lavoro, 51, 780

Roach, S. A., and Schilling, R. S. F. (1960). Brit. J. industr. Med., 17,1 .

Schilling, R. S. F. (1956). Lancet, 2, 261 and 319.

(1960). Med. d. Lavoro, 51, 754 . 